\title{
The Impact of Individual Factors on Knowledge Sharing Quality
}

\author{
Mohd Bakhari Ismail and Zawiyah M. Yusof \\ Faculty of Information Science and Technology, Universiti Kebangsaan Malaysia, Malaysia
}

\begin{abstract}
Individual factors have been known of their significant impact on knowledge sharing behaviour in organisation. It is the aim of this paper to investigate the relationship between individual factors such as awareness, trust and personality and the quality of knowledge sharing in Malaysian public agencies. Survey method employing questionnaires as technique for collecting data was used. The survey involved three selected government departments executed from October through December 2008 involving a sample of 428 respondents. The data collected was analysed using SPSS version 16.0. Factor analysis and reliability test were performed to ensure the validity and reliability of the instrument. Confirmatory factor analysis was carried out to verify the existence of three dimensions of individual factors. Analysis reveals that there is a positive and significant correlation between individual factors and the quality of knowledge sharing. The results of multiple regression analysis indicate that personality is the most significant predictor of knowledge sharing quality followed by trust and awareness.
\end{abstract}

Keywords: individual factors, knowledge sharing, public sector, Malaysia

\section{Introduction}

It is evident that through effective creation and transfer of knowledge, organisation would be able to gain competitive advantage and superior performance (Kogut \& Zander, 1992; Grant, 1996). Thus, modern organisations are striving towards managing their knowledge so as to enable it to be shared from within the organisation. This is due to the fact that knowledge is now regarded as an asset capable of giving many untold benefits that make a difference between successful and less successful organisation. A remarkable contribution of knowledge sharing is improving the quality of service delivery of an organisations particularly the public ones and these organisation are more service oriented rather than producing goods as their products. Thus, in the public sector, the term 'competitive advantage' could mean 'serving the public' as the ultimate objective of public organizations (Binz-Scharf, 2003). As such, public organization ought to manage its organizational knowledge efficiently and effectively in order to enhance the quality of service delivery.

National University of Singapore (NUS) in its survey in 2007 discovered that $35 \%$ out of 32 respondents from developing countries agreed that sharing knowledge becomes the main objective of knowledge management initiative (Yuen, 2007). Such claim is in line with AlHawamdeh (2003) who asserts that this endeavour has been considered as most important dimensions in knowledge management. Why does organisation share its knowledge? What are the factors that impacted the initiative? Previous studies proved that there are several factors affecting knowledge sharing. But these studies were merely focusing on organisational or technological perspectives. Limited studies were carried out emphasising of other factor such as individual perspective (Samied \& Wahba, 2007). Regardless of the factors researched, study on knowledge sharing initiative in Malaysia, particularly in the public sector is still at scarce

Copyright 2010 Mohd Bakhari Ismail and Zawiyah M. Yusof . This is an open access article distributed under the Creative Commons Attribution License unported 3.0, which permits unrestricted use, distribution, and reproduction in any medium, provided that original work is properly cited. Contact Author: Mohd Bakhari Ismail, e-mail: bukhisma@yahoo.co.uk 
(McAdam \& Reid, 2000; Syed Ikhsan \& Rowland, 2004).

Al-Hawamdeh (2003) suggests that it is time for researchers to now shift their studies by emphasising on individual perspective rather than on organisational and technological ones as knowledge sharing is an 'unnatural act'. In the light of this, this study is executed to address the following questions:

1. Does awareness has significant effect on knowledge sharing quality?

2. Does trust has significant effect knowledge sharing quality?

3. Does personality has significant effect on knowledge sharing quality?

In the next section, literature review related to the study is presented followed by research theoretical framework, research methodology and discussion of the results. In conclusion, the authors summarize the key findings and present some limitations of the study.

\section{Literature review}

\section{Knowledge management and knowledge sharing}

Knowledge management is defined as a process of identifying, organizing and managing knowledge resources (Al-Hawamdeh, 2003). This involves creating, generating, capturing storing, sharing and using of knowledge to support and improve individual performance (Kinney, 1998; Davenport \& Prusak, 1998). Apparently, sharing knowledge is one of the processes in knowledge management (Davenport \& Prusak, 1998). It is 'the process of transferring knowledge from a person to another in an organization' (Park et al. 2003). Knowledge sharing is a deliberate act that makes knowledge reusable by other people through knowledge transfer (Lee \& Al-Hawamdeh, 2002). Perhaps, through knowledge sharing individuals could exchange tacit or explicit knowledge, hence, together create new knowledge (Van den Hooff, 2003). The process could only occur when an individual is really interested in helping others to develop a new capability for action (Senge, 1990). For the purpose of this study, the authors adopt the definition of knowledge sharing provided by Gibbert \& Krause (2002) who defined the term as the willingness of employees in an organization to share with their colleagues the knowledge they have acquired or created.

Knowledge is of little value unless it is shared (Small \& Sage, 2006) and the significance of knowledge sharing lies in the quality of the knowledge shared. Much of the previous studies emphasised on knowledge sharing behaviour, rather than on the quality. Therefore, it is the aim of this study to research on the quality of knowledge sharing since quality knowledge becomes the main concern of a matured community (Chiu et al., 2006).

\section{Knowledge sharing in public sector}

It is a recent phenomenon that knowledge sharing gains its popularity and importance in public sector (Zhang et al., 2006). Knowledge sharing as subset of knowledge management has been given high priority and expressively stated in organisation's information policy. The motives is to improve the quality of service delivery (Thomas, 2005). For a non profit organization like government agency, knowledge sharing represents ways to increase continuous performance, and is thought to improve customers and employees satisfaction (Pan \& Scarbrough, 1998).

There is only limited information on knowledge management in public sector in Malaysia due to the fact that only a handful of research has been carried out in the country (Syed Ikhsan \& Rowland, 2004). This has inspired these authors to embark on this endeavour. The study focuses on individual related factors because to share knowledge, it starts from the individual himself/herself. It is important to identify factors affecting knowledge sharing from individual perspective because some public employees consider 'knowledge is power' and they are reluctant to share knowledge.

\section{Individual factors and knowledge sharing}

In order for knowledge management to be effective, it requires a fundamental change in the way companies run their business. This is particularly significant as the heart of any effective change is the people themselves (Davis, 1998). The knowledge of the people is created and expanded through social interaction between people and their creative activities (Nonaka \& Takeuchi, 1995). Changing people's behaviour seems to be most difficult especially promoting 
knowledge sharing among employees (Bock et al., 2005)

Previous studies reveal that people are reluctant to share knowledge though their organizational culture promotes the practice (Lu et al., 2003). According to Riege (2005), there are seventeen potential individual factors that hinder people from sharing knowledge. These include:

- lack of time to share knowledge

- fear that sharing may jeopardize job security

- lack of awareness

- dominance in sharing explicit over tacit knowledge

- apply of strong hierarchy, position-based status, and formal power

- inadequate capture, evaluation, feedback, communication, and tolerance of past mistakes that would improve individual and organizational learning effects

- differences in levels of experience

- lack of interaction

- poor verbal/written communication and interpersonal skills

- difference of age

- difference of gender

- lack of social network

- differences of education levels

- taking ownership of intellectual property because of fear of not receiving recognition and accreditation from managers and colleagues

- lack of trust in people because they misuse knowledge or take unjust credit for it

- lack of trust in the accuracy and credibility of knowledge due to the source

- differences in national culture or ethnic background; and values and beliefs associated with it.

But the list does not end here. Lee and AlHawamdeh (2002) identify a few additional individual factors that impacted the practise. These are appreciation of the importance of knowledge, communication skills, motivation, absorptive capacity, reputation, incompatible personality, disciplinary ethnocentrism and technophobia). In addition, Engstrom (2006) suggests other factors such as career satisfaction, job satisfaction and career prospect also affect knowledge sharing behaviour while Ryu et al. (2006) believe individual factors such as attitude, subjective norms and perceived behaviour also have significant role. Apparently, there are many other factors that affect knowledge sharing. This is evident when Awad \& Ghaziri (2004) suggest factors like personality and attitude; Lin (2007) suggests enjoyment in helping others and selfefficacy; and Van den Brink (2003) identifies motivations, trust and care that enable knowledge sharing. From the literatures, it is evident there are many individual related factors that influence knowledge sharing practise. This is because many researchers combined many related sociopsychological theories to develop a theoretical model to study knowledge sharing in organizations (Samieh \& Wahba, 2007). However, since the study on knowledge sharing in public sector is still at scarce (McAdam \& Reid, 2000; Syed Ikhsan \& Rowland, 2004), to the knowledge of the authors, there is as yet no well-established knowledge sharing model.

Therefore, synthesizing from literatures and authors vast experience in public sector, factors which are considered closely relevant to public sector are selected. The selection also is based on the combination of self awareness theory, social exchange theory and personality theory. This study selects only three individual factors to be included in the study. Those factors are: awareness (Lee \& Al-Hawamdeh, 2002), trust (Lee \& Al-Hawamdeh, 2002; Sharratt \& Usoro, 2003) and personality (Awad \& Ghaziri, 2004). Basically, awareness and trust are based on Lee \& AlHawamdeh actor's framework and personality, derived from Awad \& Ghaziri (2004), is a new construct added to this study's theoretical model.

\section{Awareness}

Objective Self-Awareness (OSA) theory (Duwal \& Wicklund, 1972) postulates that individual's consciousness is directed either toward one's self or the external environment. OSA is defined as a state of consciousness in which individual's attention is focused on the self (Duwal \& Wicklund, 1972). The person involve in self evaluation between one's standard and actual behaviour. The more negative the gap between standard and actual behaviour, the more negative self-evaluation becomes. In recent years, the concept of awareness has become increasingly the interest of researchers in knowledge management and virtual communities (Daneshgar 2001). They consider awareness as mechanism for enhancing collaboration and knowledge sharing in 
collaborative process (Daneshgar, 2001). Awareness at all levels of employees is the main component of successful implementation of knowledge management programme (Chong \& Pandya, 2003). Employees inclusive the top management should aware the importance of knowledge sharing (Van den Brink, 2003) to create knowledge sharing culture. However, to provide awareness for knowledge management has become the top challenge in knowledge management program (Yuen, 2007). Any organization that is at unawareness phase (Van den Brink, 2003) does not realise the contribution of knowledge against their competitors (Parlby, 1999). Preliminary awareness phase is very important for knowledge sharing success (Argani, 2009). Lee and Al-Hawamdeh (2002) suggest that the appreciation of the importance of knowledge would influence knowledge sharing among employees. The inculcation of awareness of the importance of knowledge encourage discussion process and provide space for creative thinking, risk taking and the readiness to make mistake for improvement (Hadi, 2005). In this study, awareness is defined as the degree to which an employee believes that the understanding of knowledge management and appreciation of the importance of knowledge sharing benefits will affect their knowledge sharing quality. Hence, it is hypothesized that:

\section{$H_{1}$ : Awareness has a significant effect with knowledge sharing quality.}

\section{Trust}

Social Exchange Theory (Homans, 1958) postulates that individuals exchange resources via social exchange relationship. Social exchange is characterized by unspecified personal obligations, intrinsic rewards and trust (Blau, 1964). In knowledge sharing, social exchange occurs when people interact to transfer knowledge and trust is the key and prerequisite to knowledge transfer (Davenport \& Prusak, 1998; Coleman, 1999; Disterer, 2001). Trust is the highest human communication and it is the blood of any organization. When someone has a high level of trust, they will work efficiently (Covey, 2006). Trust can be viewed as an expression of confidence between few parties during whatever exchange, in which it will not bring bad or risk through the action of other parties, or confidence that will not be exploited by any party (Jones \& George, 1998).
Trust between individuals should be started by physical interaction like face-to-face interaction (Skyrme, 1997). Whether trust encourages or restrains knowledge sharing depends on face-toface interaction (Davenport \& Prusak 1998) between individuals. Nohria and Eccles (1992) discover that face-to-face interaction is important in developing and maintaining trust. The actual mode of communication that generates high trust compared to other modes (Bos et al., 2002).

The theory of the importance of trust and knowledge sharing in organization has been supported by several empirical studies (Connelly, 2000). Pan and Scarbrough (1998) assert that environment of trust is a prerequisite to knowledge sharing. As trust is closely related to knowledge sharing (Levin et al., 2002), therefore, organization should provide an environment that enable employees to trust each other, work together, to be motivated to share knowledge and involve in discussion (Van den Brink, 2003). Such an environment is deem necessary since trust and openness could encourage active knowledge sharing behaviour by means of improving communication speed by giving mandate to organizational members to share the knowledge they possess (Von Krogh, 1998). In the contrary, distrust could hinder information sharing from taking place (Orlikowski, 1993).

In organizations that are separated geographically, electronic communication is determined as capable of playing major role in connecting them. However, without trust, geographical location and organizational distance would become psychological restriction to the process (Jones \& George, 1998). In this study, trust is defined as the degree to which an employee believes that sharing knowledge will benefit them and they will not be exploited by any party in the organization (Riege, 2005; Jones \& George, 1998). Hence, it is hypothesized that:

$$
\begin{aligned}
& \mathrm{H}_{2}: \text { Trust has a significant effect on knowledge } \\
& \text { sharing quality. }
\end{aligned}
$$

\section{Personality}

Personality can be categorised into two types, extravert and introvert (Jung, 1971). According to Jung (1971) extravert personality 'is an 'outwardturning' of libido that involves a positive movement of interest away from one's inner experience toward 
outer experience'. On the hand, introvert personality 'is an inward-tuning' of psychic energy and involves a negative movement or withdrawal of subjective interest away from outer objects and toward one's inner experience' (Allen, 2003). To Jung (1971) introvert person has more problems to interact with others compared to extraverts (Lebowitz, 1989). Many researchers believe that the ability of employees to share knowledge initially depend on their communication skills either verbal or written (Riege, 2005; Davenport \& Prusak, 1998; Hendriks, 1999). However according to Awad \& Ghaziri (2004), personality is one of the factors that influence knowledge sharing. For instance, extrovert, self-confidence and feel secure are more likely to share knowledge compared to those who are introvert, self-centred or security conscious. In this study, personality is defined as the degree to which an employee perceives themselves as extrovert or introvert, self-confidence or self-centred and feel secure or always cautious (Awad \& Ghaziri, 2004). Hence, it is hypothesized that:

\section{$\mathrm{H}_{3}$ : Personality has a significant effect on knowledge sharing quality.}

\section{Theoretical framework}

This paper adapts the framework outlined by Lee \& Al-Hawamdeh (2002) and Chiu et al. (2006) to investigate the relationship between individual factors and knowledge sharing quality emphasising on the quality of the knowledge shared. The quality of the knowledge shared becomes the main concern because though knowledge sharing does take place in organization (Van den Brink, 2003) but the quality of the knowledge shared is always of question. Knowledge shared by employees in organization is meaningless if it does not help improve individual performance which in turns lead to organizational performance. In non profit organizations, knowledge sharing is the means for continuous performance improvements and increase customer and employee satisfaction (Pan \& Scarbrough, 1998; Senge, 1997; Rumizen, 1998). The theoretical framework of the study is presented in Figure 1 below.

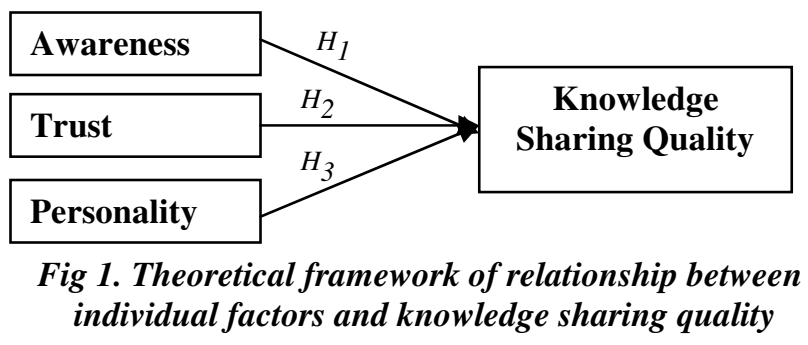

\section{Method}

\section{Population and sample}

The size of population involved for the study is about 1200. This consists of middle managers from three selected central agencies in Putrajaya. The middle managers are positioned between the top management and supporting staff. They were chosen as they are directly involved in formulating policies for public sector financial management, human resource management and socio-economic development. Knowledge is aspired and created by middle managers (Nonaka \& Takeuchi, 1995), and systematically generated at this level (McAdam \& Reid, 2000). Policy making and business development are trusted by the knowledge-based activities of government agencies (Husted et al., 2005). Stratified random sampling was used in this study and questionnaires were sent to 734 officers. 450 were returned $(61.25 \%)$ and 428 were usable.

\section{Measurement}

The instruments for individual factors were developed by the researchers based on previous literatures (Lee \& Al-Hawamdeh, 2002; Davenport \& Prusak, 1998). For knowledge sharing quality, the instruments were adapted from Chiu et al. (2006), McKinney et al. (2002) and DeLone \& McLean (2003). Knowledge sharing quality is measured in terms of relevancy, easy to understand, accuracy, completeness, reliability and timeliness. The items were adapted from McKinney et al. (2002) web-information quality and DeLone and McLean (2003) concept of information quality. Individual factors consist of 
three constructs: awareness (3 items), trust (3 items) and personality ( 3 items). Six items were used to evaluate the response towards knowledge sharing quality. Responses were measured using five Likert scales with 1=strongly disagree and $5=$ strongly agree.

\section{Findings and discussions}

\section{Demographic profile of the respondents}

The respondents' demographic characteristics are presented in the Table 1 below.

Table 1 Respondents' demographic characteristics $(n=428)$

\begin{tabular}{|c|c|c|c|}
\hline \multicolumn{2}{|c|}{ Demographic Characteristics and Classification } & Freq. & $\%$ \\
\hline Gender & $\begin{array}{l}\text { Male } \\
\text { Female }\end{array}$ & $\begin{array}{l}195 \\
233 \\
\end{array}$ & $\begin{array}{l}45.6 \\
54.4 \\
\end{array}$ \\
\hline Age & $\begin{array}{r}\quad<26 \\
26 \text { to }<30 \\
30 \text { to }<35 \\
35 \text { to }<40 \\
40 \text { to }<45 \\
45 \text { to }<50 \\
\geq\end{array}$ & $\begin{array}{r}86 \\
125 \\
96 \\
38 \\
28 \\
24 \\
31\end{array}$ & $\begin{array}{r}20.1 \\
29.2 \\
22.4 \\
8.9 \\
6.5 \\
5.6 \\
7.2\end{array}$ \\
\hline Level of Education & $\begin{array}{l}\text { PhD } \\
\text { Masters } \\
\text { First Degree } \\
\text { Others }\end{array}$ & $\begin{array}{r}2 \\
106 \\
317 \\
3\end{array}$ & $\begin{array}{r}0.5 \\
24.8 \\
74.1 \\
0.7 \\
\end{array}$ \\
\hline Position Grade & $\begin{array}{l}54 \\
52 \\
48 \\
44 \\
41\end{array}$ & $\begin{array}{r}26 \\
43 \\
74 \\
53 \\
232 \\
\end{array}$ & $\begin{array}{r}6.1 \\
10.0 \\
17.3 \\
12.4 \\
54.2 \\
\end{array}$ \\
\hline Years of service in public sector & $\begin{array}{r}<1 \\
1-5 \\
6-10 \\
11-15 \\
16-20 \\
>20\end{array}$ & $\begin{array}{r}90 \\
169 \\
55 \\
48 \\
17 \\
49\end{array}$ & $\begin{array}{r}21.0 \\
39.5 \\
12.9 \\
11.2 \\
4.0 \\
11.4\end{array}$ \\
\hline
\end{tabular}

There were 233 (54.4\%) female and 195 (45.6\%) male respondents (indicates the ratio of female and male is almost balance). Most of the respondents' age $(71.7 \%)$ ranged between 26 to 40 years old and $66.6 \%$ are junior managers (grade 41 to 44). Almost all of the respondents have a first degree and $73.4 \%$ have less than 10 years work experience in public sector

\section{Profile of individual factors and knowledge sharing quality}

Descriptive analysis for individual factors indicate that awareness (mean=4.28, S.D=.426) is the most important that affect knowledge sharing quality among government officers followed by trust (mean=4.03, S.D =.406) and personality (mean=3.98, S.D=.517). In terms of descriptive profile of knowledge sharing quality, relevant knowledge sharing has the highest mean with a statistical value of 4.11 and standard deviation = 0.462 followed by easy to understand dimension (mean 4.06, S.D=0.418), reliability (mean 3.95, $\mathrm{SD}=0.469$ ), accuracy (mean $3.85, \mathrm{SD}=0.5649$ ) and completeness (mean 3.67, SD=0.639). Based on the item mean scores, respondents have reported that relevancy as being the most important followed by easy to understand and timeliness.

\section{Goodness of measure}

Validity and reliability tests were conducted to test the appropriateness of the measure undertaken for the study. Factor analysis was conducted as a data reduction technique and also to determine whether items are tapping into the same construct. The factor analysis was done separately on independent and dependent factors because it is inappropriate to mix dependent and independent variables in a single analysis (Hair et 
al. 2006). During factor analysis, factors with eigen value of more than one would be retained for further analysis (Hair et al. 2006). Reliability test was applied to ensure consistency in measurement across time and various items in the instrument (Sekaran 2005).

\section{Individual Factors}

All the 9 items of individual factors were submitted for analysis using Principal Component Analysis (PCA). The KMO value is 0.719 which exceeds the recommended value of 0.6 (Sekaran, 2005; Hair et al., 2006; Kaiser, 1974) and the Bartlett's Test of Sphericity is significant. The results (KMO and Bartlett's) suggest that the sampled data is appropriate to proceed with a factor analysis procedure. Table 6 presents the result of varimax factor rotation of all variables for individual factors. The PCA extracted three distinct components with eigen values exceeding 1.0. Three items from awareness loaded on Factor 1 with a variance of 23.86 percent, three items from trust loaded on Factor 2 with a variance of 20.54 percent and three items from personality loaded on Factor 3 with a variance of 20.12 percent. The total variance achieved is 71.25 percent. The Cronbach's Alpha value for all the factors were between 0.698 and 0.894 meeting the acceptable value 0.6 (Sekaran, 2005; Hair et al., 2006; Kaiser, 1974). The results are presented in Table 4 and 5 below.

Table 4: KMO and Bartlett's test for individual factors instrument

\begin{tabular}{|l|l|r|}
\hline \multicolumn{2}{|l|}{ Kaiser-Meyer-Olkin of Sampling Adequacy } & 0.714 \\
\hline Bartlett's Test of Sphericity & Approx. Chi Square & 999.013 \\
\cline { 2 - 3 } & Df & 36 \\
\cline { 2 - 3 } & Significance & 0.000 \\
\hline
\end{tabular}

Table 5: Factor analysis and reliability test results on individual factors

\begin{tabular}{|c|c|c|c|}
\hline \multirow[t]{2}{*}{ Items } & \multicolumn{3}{|c|}{ Component } \\
\hline & 1 & 2 & 3 \\
\hline $\begin{array}{l}\text { B2. Based on the definition given, I understand the meaning of knowledge } \\
\text { sharing }\end{array}$ & .881 & & \\
\hline $\begin{array}{l}\text { B1. Based on the definition given, I understand the meaning of knowledge } \\
\text { management }\end{array}$ & .833 & & \\
\hline B3. I aware the importance of knowledge sharing in daily works & .737 & & \\
\hline C1. I fully trust expertise that my colleagues have & & .792 & \\
\hline $\begin{array}{l}\text { C2. I trust that help given by my colleagues while having problem in doing my } \\
\text { job. }\end{array}$ & & .761 & \\
\hline C3. I believe that my colleagues will not exploit for their own interest. & & .704 & \\
\hline D2. My self confidence is high. & & & .848 \\
\hline $\begin{array}{l}\text { D1. I am an extrovert type of person (like to know what is happening, socialize } \\
\text { and open-minded) }\end{array}$ & & & .813 \\
\hline D3. I am always cautious. (R) & & & .602 \\
\hline Cronbach Alpha & .788 & .653 & .659 \\
\hline Eigenvalues & 2.148 & 1.849 & 1.811 \\
\hline Percentage of common variance & 23.861 & 20.539 & 20.122 \\
\hline Cumulative percentage & 23.861 & 44.400 & 64.522 \\
\hline
\end{tabular}

* cut off point used is 0.30 since the sample size is more than 350 (Hair et al. 2006). All loadings less than 0.30 are not shown.

(R) - recoded. 


\section{Knowledge Sharing Quality}

Principal Component Analysis (PCA) was also performed for the 6 items of the knowledge sharing quality. The result shows that KaiserMeyer-Olkin of Sampling Adequacy (KMO) value is 0.813 . This value is excellent because it exceeds the recommended value of 0.6 (Kaiser, 1974; Pallant, 2001) and the Bartlett's Test of Spehericity is significant $(0.000)$. The results
(KMO and Bartlett's test) suggest that the sampled data is appropriate to proceed with a factor analysis procedure. The PCA extracted one distinct component with eigen values exceeding 1.0. Six items were loaded on a single factor with the variance of 53.65 percent. The Cronbach's Alpha value was 0.827 meeting the acceptable value is 0.6 (Sekaran, 2005; Hair et al., 2006; Kaiser, 1974). The results are presented in Table 6 and 7 below.

Table 6: KMO and Bartlett's test for trust instrument

\begin{tabular}{|l|l|r|}
\hline Kaiser-Meyer-Olkin of Sampling Adequacy & 0.813 \\
\hline Bartlett's Test of Sphericity & Approx. Chi Square & 878.067 \\
\cline { 2 - 3 } & Df & 15 \\
\cline { 2 - 3 } & Significance & 0.000 \\
\hline
\end{tabular}

Table 7: Factor analysis and reliability test result on service delivery

\begin{tabular}{|l|r|}
\hline \multicolumn{1}{|c|}{ Items } & Component 1 \\
\hline Q3. Knowledge that I share with my colleagues in my organization is accurate. & .780 \\
\hline Q5. Knowledge that I share with my colleagues in my organization is reliable. & .773 \\
\hline Q6. Knowledge that I share with my colleagues in my organization is timely & .730 \\
\hline Q2. Knowledge that I share with my colleagues in my organization is easy to understand. & .723 \\
\hline Q4. Knowledge that I share with my colleagues in my organization is complete. & .695 \\
\hline Q1. Knowledge that I share with my colleagues in my organization is relevant to my job. & .689 \\
\hline Cronbach Alpha & 0.827 \\
Eigenvalues & 3.29 \\
Percentage of common variance & 53.651 \\
Cumulative percentage & 53.651 \\
\hline
\end{tabular}

Overall, the results statistically show that the items used in the study are valid and measure what it is supposed to measure. The instrument is reliable (with high consistencies with Cronbach Alpha for all the factors more than 0.65) that meets the acceptable value of 0.60 (Sekaran, 2005; Hair et al. 2006; Kaiser, 1974).

\section{Test of relationship}

To identify the relationship between individual factors and knowledge sharing quality, correlation analysis was conducted. Correlation analysis indicates the strength and direction of bivariate relationship between the independent and dependent variables under studied. The result of correlation analysis shows that all the variables are significantly correlated with knowledge sharing quality. It indicates that personality $(\mathrm{r}=0.382, \mathrm{p}<0.01)$, trust $(\mathrm{r}=0.373, \mathrm{p}<0.01)$ and awareness $\quad(r=0.358, \quad p<0.01)$ have shown significant correlations with knowledge sharing quality among government officers.

A multiple regression was conducted to identify the strongest predictor and how much variance in knowledge sharing quality explained by individual factors. Table 8 show the results of multiple regression analysis. 
Table 8 Results of regression analysis

\begin{tabular}{|l|r|}
\hline & \multicolumn{1}{|c|}{$\begin{array}{c}\text { Dependent variable } \\
\text { Knowledge sharing quality }\end{array}$} \\
\hline Independent variables & \multicolumn{2}{|c|}{ (Beta Standardised } \\
Awareness & Coefficient) \\
Trust & $0.206^{*}$ \\
Personality & $0.253^{*}$ \\
& $0.266^{*}$ \\
\hline F value & $52.272^{*}$ \\
$\mathrm{R}^{2}$ & 0.270 \\
Adjusted $\mathrm{R}^{2}$ & 0.265 \\
\hline
\end{tabular}

$* \mathrm{p}<0.01$

The results of multiple regression show that individual factors have significant effects on knowledge sharing quality. The model is significant $(\mathrm{p}<0.01)$ with $\mathrm{F}$-value of 52.272 . The coefficient of determination $\left(R^{2}\right)$ is 0.270 , which indicates that $27.0 \%$ of the variance in knowledge sharing quality was explained by the independent variables (awareness, trust and personality). The results indicate that personality $(b=0.266)$, is the most significant predictor of knowledge sharing quality followed by trust $(b=0.253)$ and awareness $(b=0.206)$ Therefore it can be concluded that all hypotheses $\left(\mathrm{H}_{1}, \mathrm{H}_{2}\right.$ and $\left.\mathrm{H}_{3}\right)$ were supported.

\section{Conclusion}

Findings of the study proved that reveal the purpose of this study i.e. to identify the relationship between individual factors and knowledge sharing quality is successfully achieved. Individual factors (awareness, trust and personality) correlate significantly with knowledge sharing quality. Personality seems to be the most significant predictor on the quality of knowledge sharing, followed by trust and awareness. This finding is of help to the government of Malaysia in formulating a new policy to encourage the sharing of knowledge among employees in all its agencies. It is time for the government of Malaysia to organize programmes and trainings that could help in creating awareness, trust and building the appropriate personality suitable for the endeavour amongst its staff, the entire public servants. It is evident that any fundamental change should start from the people. Without the appropriate personality, awareness and trust, knowledge sharing in public sector will all in vain.
Continuous awareness programmes could help to change worker's personality, increase their awareness and build trust among themselves.

Though this study has achieved its goal, but it is also not without limitation. First, the scope of the study was restricted to only three agencies located in Putrajaya. Therefore, generalizing the findings to government agencies nationwide can be questioned. Second, the study relies merely on quantitative approach. It is suggested that for future study qualitative approach by means of open ended interview is to be adopted to yield information not obtainable for questionnaires. Third, study on knowledge sharing at operating agencies at state, district or local councils level is also worth to embark on. A comparative study between public and private sectors could also be considered. Fourth, this study only concentrates on knowledge sharing quality rather than form the quantity aspect. It is useful to combine knowledge sharing form both the quality and quantity aspects in order to reap the benefits of the practice in maximum. Finally, the study focuses only on three factors from individual perspective. Future research should extend its scope to other individual factors such as other types of personality.

\section{References}

Al-Hawamdeh, S. (2003), Knowledge management cultivating knowledge professionals. Chandos Publishing, Oxford.

Allen, B.P. (2003), Personality theories: Development, growth and diversity, $4^{\text {th }}$ edition. Pearson Education Inc., Boston USA. 
Argani, N. (2009), "Expertise Management in Nuclear Engineering Business," [Online] [Retrieved March 30, 2009] http://www.iaea.org/inisnkm/nkm/ documents/nkmCon2007/fulltext/FP/IAEA-CN153-2-P-09fp.pdf

Awad, E.M. and Ghaziri, H.M. (2004), Knowledge management. Pearson Education Inc., New Jersey.

Binz-Scharf, M. C. (2003), Exploration and Exploitation: Knowledge Sharing In Digital Government Projects. PhD Dissertation. St. Gallen University. [Online] Retrieved August 10, 2008 from: //www.unisg.ch/www/edis.nsf/ wwwDisplayIdentifier/ 2828/\$FILE/dis2828.pdf

Blau, P. (1964), Exchange And Power In Social Life. John Wiley \& Sons, New York.

Bock, G-W., Zmud, R.W., Kim, Y.G. (2005), 'Behavioral intention formation in knowledge sharing. Examining the Roles of Extrinsic Motivators, Social-Psychological Forces and Organizational Climate', MIS Quarterly 29 (1), 87111.

Bos, N., Olson, J.,Gergle, D. Olson, G. \& Wright, Z. (2002), 'Effects of four computer-mediated communication channels on trust development,' Proceedings of Conference on Human Factors in Computing Systems (CHI), Minneapolis MN, New York: ACM Press, April, 135-140.

Chiu, C. M., Hsu, M.H. \& Wang, E.T.G. (2006), 'Understanding knowledge sharing in virtual communities: An integration of social capital and social cognitive theories', Decision Support Systems, 42 (3), 1872-1888.

Coleman, D. (1999), 'Groupware: Collaboration and Knowledge Sharing,' in Knowledge management handbook, Liebowitz, J. (ed.). CRC Press, Boca Raton.

Cong, X. and Pandya, K. (2003), 'Issues of knowledge management in the public sector', Electronic Journal of Knowledge Management 1 (2), 25-33.

Connelly, C. 2000 Predictors of knowledge sharing in organizations. Unpublished Master Thesis, Queens School of Business, Queen's University, Kingston, Ontario Canada.
Covey, S.M.R \& Merrill, R. (2006), The speed of trust: the one thing that changes everything. Free Press.

Daneshgar, F. (2001). Maintaining collaborative process awareness as a mechanism for knowledge sharing. 2nd European Conference on Knowledge Management, Bled, Slovenia.

Davenport, T.H. and Prusak, L. (1998), Working knowledge: How organizations manage what they know, Harvard Business School Press, Boston, Massachusetts.

Davis, M. C. (1998), Knowledge management, Information Strategy: The Executive's Journal 15 (1), Fall, 11-22,

DeLone, W.H. \& Mc Lean, E.R. (2003), 'The DeLone and Mc Lean model of information systems success: a ten year update', Journal of Management Information Systems 19 (4), 9-30.

Disterer, G. (2001) 'Individual and social barriers to knowledge transfer', [Online] [Retrieved Disember 12, 2005] from:

//www.hicss.hawaii.edu

Duval, S., \& Wicklund, R. A. (1972), A theory of objective self awareness. Academic Press, New York.

Engstrom, T.E.J. (2003), Sharing knowledge through mentoring: Performance improvement 42 (8), 36-42. [Online] [Retrieved August 21, 2006] http://www.ispi.org

Gibbert, M. and Krause, H. (2002), 'Practice exchange in a best practice marketplace,' in Knowledge management case book: Siemen Best Practices, Davenport, T.H and Probst, G.J.B. (eds.). Publicis Corporate Publishing, Erlangen, Germany.

Grant, R.M. (1996), 'Toward a Knowledge-Based Theory of the Firm', Strategic Management Journal, 17 (Winter Special Issue), 109-122.

Hadi, Z. A. (2005) 'Pembentukan organisasi berasaskan pengetahuan (K-Based organization): satu transformasi perkhidmatan awam', Jurnal Pengurusan Awam 4 (1), 37-50. 
Hair, J.E., Anderson, R.E. Tatham, R.L. \& Black, W.C. (2006), Multivariate Data Analysis. $5^{\text {th }}$ Ed. Prentice Hall, Upper Saddle River.

Hendriks, P. (1999), 'Why Share Knowledge? The Influence of ICT on the Motivation for Knowledge Sharing', Knowledge \& Process Management, 6 (2), 91-100.

Homans, G.C. (1958), 'Social Behavior as

Exchange', American Journal of Sociology, 63 (6), 597-606.

Husted, K., Michailova, S. and Minbaeva, D. (2005), Knowledge sharing and organizational performance: The role of extrinsic and intrinsic motives. The $8^{\text {th }}$ International human resource management conference, Cairns, Austarlia June 1417, 2005. [Online] [Retrieved January 8, 2007] http://jobfunctions.bnet.com/whitepaper.aspx? docid $=271705$

Jones, G.R. and George, J.M. (1998), 'The experience and evolution of trust: Implications for cooperation and teamwork', Academy of management review 23 (3), 531-546.

Jung, C. G. Psychological Types (1971), (Trans. R.F.C Hull). Collected works. (6), Princeton University Press, Princeton, New Jersey.

Kaiser, H. (1974), An index of factorial simplicity. Psychometrika 39, 31-36.

Kinney, T. (1998), 'Knowledge management, intellectual capital and adult learning', Adult Learning 10 (2), 2-5.

Kogut, B. \& Zander, U. (1992), 'Combinative Capabilities and the Replication of Technology', Organization Science 3 (3), 383-397.

Lebowitz, M. (1989), 'Religious immoralism', Kenyon Review, Spring, 154-156.

Lee, C.K. and Al-Hawamdeh, S. (2002), 'Factors impacting knowledge sharing', Journal of Information and Knowledge Management, 1 (1), 49-56.

Levin, D.Z., Cross, R., Abrams, L.C. and Lesser, E.L. (2002), 'Trust and knowledge sharing: A critical combination,' in Creating value with knowledge. Lesser, E.L. and Prusak, L. (eds.), Oxford University Press, New York:
Lin, H. F. (2007), 'Knowledge sharing and firm innovation capability: an empirical study', International Journal of Manpower 28 (3/4), 315332.

Lu, L. \& Leung, K. (2003), 'A Public Goods Perspective on knowledge sharing', Center for Innovation Management and Organizational Change.

McAdam, R. and Reid, R. (2000), 'A comparison of public and private sector perception and use of knowledge management.' Journal of European Industrial Training, 24 (6), 317-329.

McKinney, V., Yoon, K. \& Zahedi, F.M. (2002), 'The measurement of web-customer satisfaction: An expectation and disconfirmation approach', Information Systems Research 11 (3), 296-315.

Nohria, N. and R. G. Eccles. (1992), 'Face-to-Face: Making Network Organizations Work.' In Networks and Organizations: Structure, Form and Action, N. Nohria and R. C. Eccles (eds.) Harvard Business School Press, Boston.

Nonaka, I. and Takeuchi, H. (1995), The knowledge-creating company: How Japanese companies create the dynamics of innovation. Oxford University Press, New York.

Olikowski, W.J. (1993) 'Learning from notes. Organizational issues in groupware implementation', The Information Society 9 (3), 237-250.

Pallant, J. (2001), A Step by Step Guide to Data Analysis Using SPSS for Windows, Open University Press, Buckingham, UK.

Pan, S. L., \& Scarbrough, H. (1998), 'A sociotechnical view of knowledge sharing at Buckman Laboratories', Journal of Knowledge Management 2 (1), 55-66.

Park, H.S \& Im, B.C . (2003), A study on the knowledge sharing behaviour of local public servants in Korea' [Online][Retrieved April 27, 2009] http ://www.kapa21.or.kr/down/ 2003

Parlby, D. (1999),. The knowledge journey: A Business guide to knowledge management, KPMG Consulting, London. [Online] [Retrieved January 
15, 2007] http: //www.kpmg.co.uk/kpmg/ uk/ services/manage/pubs/ journey.html.

Riege, A. (2005), 'Three-dozen knowledge-sharing barriers managers must consider', Journal of Knowledge Management 9 (3), 18-35.

Rumizen, M. C. (1998), 'Report of the second comparative study of knowledge creation conference', Journal of Knowledge Management 2 (1), 77-81.

Ryu, S., Hee, H. S. and Han, I. (2003), 'Knowledge sharing behaviour of physicians in hospitals', Expert systems with application 25, 113-122. [Online] [Retrieved November 23, 2006] http://www.elsevier.com/locate/eswa

Samieh, H. M. \& Wahba, K. (2007), Knowledge sharing behaviour from game theory and sociopsychological perspectives.[Online][Retrieved April 29, 2009] http:// csdl2.computer.org/comp/ proceedings/

hicss $/ 2007 / 2755 / 00 / 27550187$ c.pdf

Sekaran, U. (2005), Research methods for business - a skill building approach (4th edition). John Wiley and Sons, New York.

Senge, P. M. (1990), The fifth discipline: the art and practice of the learning organization. Currency/Doubleday, New York.

Senge, P.M. (1997), 'Creating Learning Communities', Executive Excellence 14 (3), 17-18.

Sharratt, M. \& Usoro, A. (2003), 'Understanding knowledge-sharing in online communities of practice', Electronic Journal of Knowledge Management 1 (2), 187-196.

Skyrme, D.J (1997), From information to knowledge management: Are you prepared? [Online] [Retrieved January 11, 2007] http://www.skyrme.com/pubs/ on97full.htm

Small, C. T. \&. Sage, A.P. (2006), 'Knowledge management and knowledge sharing: A review', Information Knowledge Systems Management (5), 153-169.

Syed Ikhsan, S.O.S. and Rowland, F. (2004), 'Benchmarking knowledge management in a public organisation in Malaysia', Benchmarking: An International Journal, 11 (3), 238-266.
Thomas, E.J. (2005), Knowledge management in the public and private sector: a synthetic analysis the contemporary literature. Masters Thesis. Pennsylvania State University.

Van den Brink, P. (2003), Social, individual and technological conditions that enable knowledge sharing. Phd Thesis. Universiteit van Amsterdam.

Van den Hooff, B., Elving, W.J.L., Meeuwsen, J.M. \& Dumoulin, C.M. (2003), Knowledge Sharing in Knowledge Communities, in Communities and Technologies. M.H. Huysman, V. Wulf. \& E. Wenger (eds.) Kluwer Academic Publishers. Deventer.

Von Krogh, G. (1998), 'Care in Knowledge Creation', California Management Review 40 (3), 133-153.

Yuen, Y. H. (2007), Overview of Knowledge management in the public sector. [Online]

[Retrieved August 10, 2008] http: unpan1.un.org/intradoc/groups/ public/documents/unpan/unpan026041.pdf

Zhang, J., Faerman, S.R. and Cresswell, A.M. (2006), The effect of organizational/technologicl factors and the nature of knowledge on knowledge sharing. [Online] [Retrieved Disember 12, 2005], http://www.hicss.hawaii.edu 